\title{
Proses Kreatif: Edison dan Bell dalam Revolusi Komunikasi
}

\author{
Andi Susilo \\ andi.susilo@mail.com \\ Jurusan Teknik Komputer \\ STIMIK AKI, Semarang
}

\begin{abstract}
Everybody knows Edison is one of greatest Inventors in the world, eventhough He just improved other people's creation, But He worked hard night and day to get the inspiration. On other hand Bell did invent the telephone on the simple way. What we would like to know about them, it may be on the way of their different creative process. This article describes the revolution of communication technology is begun from both of them
\end{abstract}

\section{Pendahuluan}

Kegiatan berpikir banyak dilakukan dalam pendidikan formal yang menekankan kepada kemampuan-kemampuan analisis. Terdapat jenis cara berpikir yang memusatkan pada eksplorasi ide-ide, membangkitkan kemungkinan-kemungkinan, mencari alternatif banyak jawaban yang benar daripada hanya mengambil satu jawaban yang benar. Kedua jenis cara berpikir adalah vital untuk sebuah keberhasilan kerja. Kami menurunkan kedua jenis cara berpikir ini seperti berikut:

\begin{tabular}{|l|l|}
\hline Berpikir Kritis & Berpikir Kreatif \\
\hline Analitik & Generatif \\
\hline Konvergen & Divergen \\
\hline Vertikal & Lateral \\
\hline Probability & Possibility \\
\hline Judgement & Suspended Judgement \\
\hline
\end{tabular}

Majalah Ilmiah Informatika, Vol. 4, No. 10, Maret 2002

ISSN 1411-6413 1 


\begin{tabular}{|l|l|}
\hline Focused & Diffuse \\
\hline Obyektif & Subyektif \\
\hline Otak Kiri & Otak Kanan \\
\hline Verbal & Visual \\
\hline Linier & Asosiatif \\
\hline
\end{tabular}

Di dalam sebuah aktivitas seperti pemecahan masalah, kedua jenis cara berpikir ini penting untuk kita. Pertama kita harus menganalisa masalah kemudian harus membangkitkan kemungkinan solusi-solusi, berikutnya kita memilih dan mengimplementasikan solusi terbaik dan akhirnya, mengadakan evaluasi keefektivitasan dari solusi-solusi. Seperti yang dapat anda lihat, proses ini mengungkapkan sebuah pergantian diantara dua jenis cara berpikir kritis dan kreatif, kedua jenis cara berpikir ini beroperasi bersama-sama dalam sejumlah besar waktu dan tidak benar-benar terpisah.

\section{Kreativitas}

Apakah Kreativitas itu? Terdapat sejumlah besar definisi kreatif dari beberapa ahli yang terlibat dalam penyelidikan tentang proses kreatif. Beberapa definisi seperti berikut ini:

1. Kemampuan. Sebuah definisi sederhana kreativitas adalah kemampuan untuk mengimajinasikan atau menemukan sesuatu yang baru. Kreativitas bukan kemampuan untuk menciptakan dari yang tidak ada menjadi ada (Hanya Tuhan yang dapat melakukannya). Tetapi kemampuan untuk mewujudkan ide-ide baru dengan mengkombinasikan, mengubah, atau mengaplikasikan ulang ide-ide yang sudah ada. Beberapa ide kreatif mengandung sesuatu yang brilian, sementara yang lainnya cukup sederhana, menjadikan ide-ide praktis yang agaknya tidak terpikirkan sebelumnya.

Setiap manusia yang dilahirkan memiliki kemampuan kreatif dalam kadar yang berbeda seperti perbedaan nilai IQ. Tetapi kreativitas dapat dikembangkan. Ahli Psikologi berkebangsaan Amerika Serikat William James pernah berkata bahwa "Manusia hanya menggunakan 10 persen dari seluruh kemampuan berpikirnya".

Proses Kreatif: Edison dan Bell dalam Revolusi Komunikasi (Andi Susilo) 
Seringkali yang dibutuhkan untuk menjadi kreatif adalah membuat sebuah komitmen kepada kreativitas dan meluangkan waktu untuk itu.

2. Sikap. Kreativitas juga sebuah sikap yaitu kemampuan untuk menerima perubahan dan sesuatu yang baru, kesediaan untuk memainkan ide-ide dan kemungkinankemungkinan, fleksibel dalam melihat sesuatu, memandang sesuatu secara positif, sementara mencari banyak cara untuk menyempurnakannya. Kami mensosialisasikannya dengan hanya sejumlah hal-hal kecil yang biasa misalnya Coklat rasa Strawberry. Orang-orang kreatif menyadari bahwa terdapat kemungkinan-kemungkinan lain. Contohnya keju kacang, sandwich pisang atau coklat rasa mangga.

3. Proses. Orang-orang kreatif bekerja dengan keras dan terus-menerus memperbaiki ide-ide dan penyelesaian-penyelesaian, dengan membuat setahap demi setahap kemurnian kerja mereka. Beberapa kerja kreatif yang unggul dihasilkan dari sambaran brilian dan aliran deras kreativitas. Jauh lebih mendekati kepada kenyataan dimana sejarah menunjukkan perusahaan mengambil hasil penemuan dari penemupenemu untuk memasarkan hasil karya mereka karena mereka selalu mencoba membuatnya menjadi lebih baik. Orang-orang kreatif tahu bahwa selalu ada ruang untuk perbaikan.

\section{Metode-metode Kreatif}

Beberapa metode telah diidentifikasikan untuk menciptakan hasil-hasil kreatif. Disini terdapat lima jenis metode klasik:

1. Evolusi. sebuah metode melalui peningkatan proses perbaikan. Tangkai ide-ide baru dari ide yang lain, solusi-solusi baru dari yang sebelumnya. Ide-ide baru sedikit diperbaiki dari ide-ide yang lama. Banyak hal sangat canggih yang kita nikmati saat ini berkembang melalui periode panjang dengan kenaikan konstan. Sebagai contoh: Lihatlah sejarah automobile atau segala produk dari kemajuan teknologi. Dengan model baru, dari perbaikan yang dibuat. Tiap-tiap model baru membangun hasil-hasil 
kreativitas dari model sebelumnya, dimana perbaikan-perbaikan secara ekonomi, kesesuaian, dan daya tahan mengambil tempat. Disini kreativitas menempatkan kemurniannya dengan perbaikan-perbaikan tahap demi tahap lebih dari sesuatu yang baru sepenuhnya. Metode evolusi kreativitas juga mengingatkan kita kepada prinsip kritis: setiap masalah yang telah dipecahkan dapat dipecahkan lagi secara lebih baik. Pemikir-pemikir kreatif tidak menganut ide dimana satu kali sebuah masalah telah dipecahkan, selanjutnya dilupakan begitu saja atau dengan menduga jika sesuatu telah rusak maka tidak perlu diperbaiki. Filosofi seorang pemikir kreatif adalah "tiada hal yang membuat penyempurnaan menjadi tidak berarti."

2. Sintesis. Dengan metode ini, dua atau lebih ide dikombinasikan menjadi ide ketiga yaitu sebuah ide baru. Mengkombinasikan sebuah majalah dengan sebuah tape audio memberikan ide sebuah majalah yang dapat didengarkan, sesuatu yang sangat berguna bagi penyandang tunanetra.

3. Revolusi. Kadang-kadang ide baru yang paling bagus adalah sesuatu yang benarbenar baru. Sementara itu sebuah perbaikan evolusioner bisa menyebabkan seorang profesor bertanya " Bagaimana saya bisa membuat kuliah saya menjadi lebih baik dan jauh lebih baik lagi? ". Sebuah ide yang revolusioner bisa menjadi "Mengapa tidak berhenti mengajar, dan memerintahkan mahasiswa untuk saling mengajarkan ke temannya yang lain, bekerja dalam sebuah tim dan merepresentasikan laporan?"

4. Aplikasi Ulang (Reapplication). Melihat sesuatu yang sudah lama dikenal dengan cara baru. Menghilangkan prasangka, pengharapan, dugaan-dugaan dan menemukan bagaimana sesuatu dapat diaplikasikan ulang. Seseorang yang kreatif bisa saja menuju ke tempat barang rongsokan, melihat kemudian mengubahnya menjadi karya seni dari sebuah transmisi mobil jenis $\mathrm{T}$ tua (hasil penemuan Henry Ford), mengecatnya dan meletakkannya di ruang tamu.

5. Mengubah Arah (Changing Direction). Banyak pemecahan kreatif muncul ketika perhatian bergeser dari satu sudut masalah ke masalah yang lain. Ini sering disebut

Proses Kreatif: Edison dan Bell dalam Revolusi Komunikasi (Andi Susilo) 
dengan Creative Insight. Contoh klasik, sebuah departemen jalan raya mencoba untuk mencegah anak-anak bermain skateboard di dalam sebuah parit saluran jalan air. Departemen jalan raya meletakkan sebuah pagar untuk menjaga anak-anak keluar: mereka malah bermain-main di sekelilingnya. Departemen jalan raya kemudian memasang pagar yang lebih panjang: anak-anak melubanginya. Departemen kemudian memasang lagi pagar yang lebih kuat: anak-anak melubanginya kembali. Departemen kemudian memasang tanda peringatan pada pagar, peringatan tersebut diabaikan. Akhirnya seseorang memutuskan untuk mengubah arah dan bertanya "Apakah yang benar-benar menjadi masalah disini?. Bukanlah anak-anak yang tetap bisa melewati rintangan, tetapi mereka ingin bermain skateboard di parit. Jadi bagaimanakah cara kita dapat mencegah mereka bermain skateboard di parit?” Solusinya adalah menghilangkan keinginan mereka dengan mengalirkan sesuatu yang nyata ke dalam parit untuk menghilangkan kurva halus. Sudut tajam yang diciptakan secara nyata membuat anak-anak tidak mungkin bermain skateboard dan aktivitas berhenti, tidak ada masalah dengan skateboard dan pagar lagi.

\section{Sikap negatif yang menghalangi kreativitas}

1. Jangan, ini adalah sebuah masalah. Reaksi kepada suatu masalah seringkali lebih besar daripada masalahnya sendiri. Banyak orang menghindari atau mengabaikan masalah sampai menjadi sangat terlambat, Karena orang-orang ini tidak pernah belajar dengan tepat secara emosional, psikologi dan tanggapan-tanggapan praktis. Sebuah masalah adalah sebuah kesempatan. Orang-orang yang paling bahagia menyambut dan bahkan mencari penyelesaian masalah, menemuinya sebagai tantangan-tantangan dan kesempatan-kesempatan untuk memperbaiki berbagai hal. Definisi sebuah masalah adalah 1. Melihat perbedaan antara apa yang anda miliki dan apa yang anda inginkan atau 2. Mengenal atau mempercayai bahwa terdapat keadaan yang lebih baik dari situasi sekarang atau 3. Kesempatan untuk bertindak positif. Mencari masalah secara agresif akan membangun kepercayaan diri, merasakan kebahagiaan dan membentuk pengendalian diri yang baik dalam kehidupan anda. 
2. Pekerjaan itu tidak dapat dilakukan. Sikap ini, berakibat menyerah sebelum berperang. Dengan menganggap sesuatu tidak dapat dilakukan atau suatu masalah tidak dapat dipecahkan. Seseorang memberikan masalah sebagai daya atau kekuatan yang tidak dimiliki sebelumnya. Lihatlah sejarah dari sikap orang-orang yang skeptis: Manusia tidak akan pernah dapat terbang, penyakit tidak akan pernah dapat diatasi, Roket tidak akan pernah dapat meninggalkan atmosfer bumi, pegunungan Mount Everest tidak akan pernah dapat ditaklukkan.

\section{Saya tidak dapat melakukannya, atau tidak ada yang dapat saya lakukan.}

Beberapa orang berpikir, mungkin masalah hanya dapat dipecahkan oleh orang-orang yang ahli. Tetapi tidak oleh saya, saya tidak cukup pandai, saya bukan insinyur, saya bukan seorang pilot dan seterusnya.

Siapakah Wright bersaudara yang menemukan pesawat terbang? Insinyur penerbangankah mereka? mereka adalah tukang mekanik sepeda. Mesin pemisah biji kapas ditemukan oleh seorang pengacara dan tutor yang dikenal dengan baik, Eli Whitney. Alat pemadam kebakaran ditemukan oleh seorang kapten, George Manby. Bahkan, hal utama yang dibuat oleh penulis-penulis baru-baru ini dari badan hukum yang bermutu menyatakan bahwa inovasi-inovasi di dalam industri berasal dari individu (bukan sebuah kelompok riset). General Motors menemukan Freon, Pendingin kimia dan tetraethyl yang mengarahkan kepada zat aditif minyak tanah. Kodachrome ditemukan oleh dua orang musisi.

\section{Kreativitas salah satu ciri dari keberbakatan}

Joseph S. Renzulli, direktur The National Research Center on the Gifted and Talented, Universitas Connecticut dalam makalahnya berjudul "The Three-Ring Conception of Giftedness" mengemukakan bahwa terdapat tiga ciri dari orang-orang berbakat, seperti dijelaskan pada bagian ini: Riset pada orang kreatif-produktif telah secara konsisten memperlihatkan bahwa meskipun tidak ada satu kriteria (ukuran) yang dapat digunakan untuk menentukan keberbakatan, seseorang yang telah berhasil dikenal

Proses Kreatif: Edison dan Bell dalam Revolusi Komunikasi (Andi Susilo) 
karena keunikan prestasi dan sumbangan kreatif mereka memiliki tiga ciri kelompok yang berhubungan satu sama lain. Kelompok ini terdiri dari kemampuan diatas rata-rata, pengikatan diri terhadap tugas, dan kreativitas. Penting untuk menunjukkan bahwa tidak hanya satu ciri yang menghasilkan bakat. Agaknya interaksi diantara 3 ciri dimana riset telah memperlihatkan unsur-unsur utama bagi kerja kreatif-produktif (Renzulli, 1978). Interaksi ini diwakili oleh bagian yang diarsir pada gambar. Juga penting untuk mengarahkan bahwa masing-masing ciri memainkan sebuah peran penting dalam menyumbangkan tingkah laku anak berbakat.

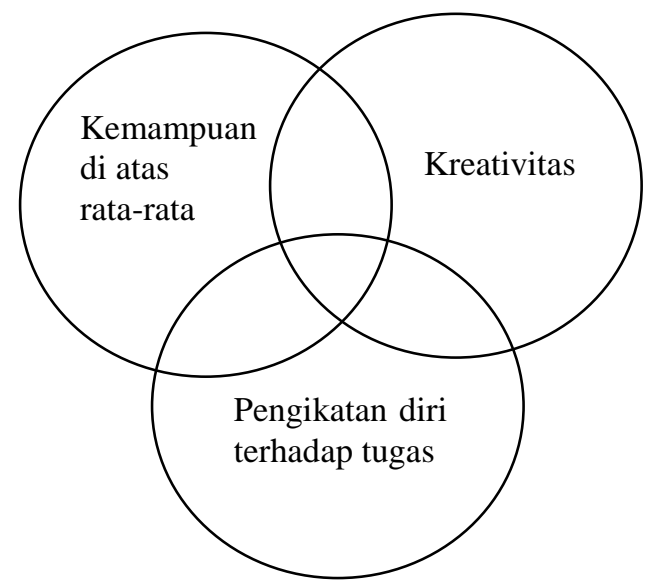

Tiga ciri konsep pembentuk keberbakatan menurut Renzulli

\section{Kemampuan di atas rata-rata (Well Above Average Ability)}

Kemampuan diatas rata-rata dapat didefinisikan kedalam dua cara yaitu kemampuan umum dan kemampuan spesifik.

Keтатриап итит berisi kapasitas untuk mengolah informasi, menggabungkan pengalaman-pengalaman yang menghasilkan respons yang tepat dan penyesuaian diri didalam situasi yang baru, dan kapasitas keterlibatannya dalam berpikir abstrak. Contoh dari kemampuan berpikir umum adalah berpikir verbal dan numerik, spatial relations, daya ingat, dan kelancaran menggunakan kata. Kemampuan ini biasanya diukur melalui tes aptitude atau inteligensia dan secara luas diterapkan pada beranekaragam situasi belajar tradisional. 
Kemampuan spesifik berisi kapasitas untuk memperoleh pengetahuan, keahlian, atau kemampuan untuk bekerja didalam satu atau lebih aktivitas khusus dan dalam area tertentu. Kemampuan-kemampuan ini didefinisikan di dalam sebuah sikap yang mewakili cara didalam keberadaan manusia mengekspresikan dirinya sendiri pada kehidupan nyata. Contoh dari kemampuan spesifik misalnya kemampuan dalam bidang kimia, balet, matematika, komposisi musik, memahat dan memotret. Banyak kemampuan spesifik bagaimanapun juga tidak dapat dengan mudah diukur melalui tes, oleh karena itu, bidang semacam seni harus dievaluasi melalui satu atau lebih kemampuan yang didasarkan pada teknik penaksiran.

Meskipun pengaruh inteligensia, seperti yang terukur sungguh jelas berbeda-beda dengan kemampuan pada bidang kemampuan spesifik, banyak ilmuwan telah menemukan bahwa kecakapaan kreatif tidak harus merupakan sebuah fungsi dari kemampuan inteligensia yang terukur.

Dalam studi yang berhubungan dengan penafsiran dimensi yang beranekaragam dari bakat mahasiswa di universitas, Holland dan Austin (1962) menemukan bahwa:

Mendapatkan angka yang baik di perguruan tinggi memiliki hubungan kecil dengan lebih jauh dan lebih jauh lagi kecakapan sosial yang relevan. Tentu saja di beberapa perguruan tinggi, lebih tinggi nilai akademik mahasiswa, lebih kecil lagi bahwa ia adalah seseorang dengan potensi kreatif. Jadi agaknya diharapkan untuk memperluas kriteria kami dari bakat seseorang (Hal. 132-133).

Sebuah studi yang dilaksanakan oleh American College Testing Program (Munday \& Davis, 1974) berjudul "Varieties of Accomplishment After College: Perspectives on the Meaning of Academic Talent," menyimpulkan bahwa:

Kecakapan setelah dewasa ditemukan tidak memiliki korelasi dengan kemampuan akademik, termasuk skor tes, nilai di SMA, dan di perguruan tinggi. Bagaimanapun juga kecakapan setelah dewasa dihubungkan kepada kecakapan non akademik (ekstra kurikuler) di SMA sebagai perbandingan. Hal ini menyarankan bahwa banyak anak-anak berbakat berhubungan dengan kesuksesan hidupnya dikemudian hari bisa diidentifikasikan dan dijaga oleh institusi pendidikan (Hal. 2).

Kesimpulan yang paling dapat dipertahankan mengenai penggunaaan tes inteligensia yang dapat dikemukakan saat ini didasarkan pada penemuan hasil riset yang berhubungan Proses Kreatif: Edison dan Bell dalam Revolusi Komunikasi (Andi Susilo) 
dengan "threshold effect". Ditinjau dari riset yang dilaksanakan oleh Chambers (1969), Stein (1968), dan Walberg (1969, 1971) menunjukkan bahwa kecakapan diberbagai bidang membutuhkan tingkatan minimal dari inteligensia, tetapi diluar tingkat ini derajat pencapaian (hasil yang dicapai) adalah lemah jika diasosiasikan dengan inteligensia. Didalam studi terhadap kreativitas, secara umum diakui bahwa hampir dapat dipastikan tinggi, meskipun tidak luarbiasa tingkat kecerdasannya adalah penting untuk derajat yang tinggi dari kecakapan kreatif (Barron, 1969; Campbell, 1960; Guilford, 1964, 1967; McNemar, 1964; Vernon, 1967).

Riset pada threshold effect menunjukkan bahwa bidang yang berbeda membutuhkan derajat yang berbeda-beda dari inteligensia untuk kecakapan tingkat tinggi. Didalam bidang matematika dan fisika korelasi tingkat kecerdasan yang diukur dengan orisinilitas dari pemecahan masalah, mengarah positif, tetapi sungguh rendah. Korelasi antara inteligensia dan kualitas kerja pelukis, pemahat, desainer adalah nol atau hampir negatif (Barron, 1968).

Meskipun sulit untuk menentukan secara tepat seberapa besar tingkat kecerdasan yang diukur, penting untuk tingkatan tinggi dari kecakapan kreatif-produktif didalam bidang yang diberikan, terdapat sebuah konsensus diantara ahli-ahli riset (Barron, 1969; Bloom, 1963; Cox, 1926; Harmon, 1963; Helson \& Crutchfield, 1970; Mackinnon, 1962, 1965; Oden, 1968; Roe, 1952; Terman, 1954) bahwa sedikitnya IQ 120 atau lebih variabel-variabel yang lain menjadi makin penting. Variabel-variabel yang dimaksud adalah pengikatan diri terhadap tugas dan kreativitas.

\section{Pengikatan diri terhadap tugas (Task Commitment)}

Ciri kedua secara konsisten ditemukan pada orang-orang kreatif-produktif adalah dimaksudkan pada bentuk motivasi yang dikenal sebagai task commitment. Dimana motivasi biasanya didefinisikan sebagai proses energi yang menggerakkan seseorang untuk melakukan suatu tindakan. Istilah yang paling sering digunakan untuk mendeskripsikan task commitment adalah ketekunan, ketabahan (daya tahan), kerja keras, membaktikan diri pada pekerjaannya sendiri, kepercayaan diri, dan keyakinan akan kermampuan dirinya yang membawa kepada kerja besarnya. Ciri lain sebagai tambahan yaitu kecerdikan (lekas mengerti) (Albert, 1975) dan kepekaan dalam identifikasi 
masalah yang penting (utama) (Zuckerman, 1979), penyelidikan kepada orang-orang dengan prestasinya yang luar biasa telah menunjukkan pesona tertentu dan keterlibatan dengan persoalan utama dari bidang yang diminatinya hampir selalu menjadi pelopor dari keaslian dan kemandirian kerjanya. (Barron, 1962, hal. 3).

Warisan dari kedua ahli psikologi Sir Francis Galton dan Lewis Terman secara nyata menunjukkan bahwa task commitment adalah sebuah bagian penting dari orang-orang berbakat. Meskipun Galton adalah seorang pendukung yang kuat dari sifat bakat karena keturunan yang ia namakan dengan "natural ability," namun ia menganut kuat kepada keyakinan bahwa kerja keras adalah bagian dari bakat.

Studi monumental dari Lewis Terman tidak diragukan lagi mewakili riset yang telah luas diketahui dan sering dikutip pada karakteristik orang-orang berbakat. Studi Terman bagaimanapun juga telah (tanpa disengaja) meninggalkan sebuah warisan abadi karena kebanyakan orang telah percaya kepada pendapat awal Terman, daripada kesimpulannya yang ia capai setelah beberapa dekade dari penyelidikan intensifnya. Penting untuk mempertimbangkan kesimpulan berikut yang ia capai sebagai hasil studi 30 tahun dari populasi awalnya:

Sebuah analisis teliti yang dibuat dari 150 orang paling sukses dan 150 orang yang kurang berhasil diantara subyek orang-orang berbakat didalam sebuah percobaan untuk mengenal beberapa faktor non intelektual yang mempengaruhi sukses dalam hidup.....Subyek yang kurang sukses tidak berbeda tingkat kecerdasannya dari hasil tes, jelaslah bahwa prestasi dari tokoh-tokoh terkemuka memerlukan lebih daripada kecerdasan yang tinggi. Hasil ini menunjukkan bahwa faktor kepribadian secara ekstrim menjadi penentu utama dari prestasi seseorang.....empat ciri (baik kelompok yang berhasil dan kurang berhasil) yang membedakan secara luas adalah ketekunan dalam bekerja sampai selesai, integrasi mencapai tujuan, kepercayaan diri, dan bebas dari perasaan rendah diri. Gambaran keseluruhan perbedaan yang besar antara dua kelompok tersebut adalah penyesuaian diri secara sosial dan emosional dan didalam pengendalian dirinya dalam mencapai sukses.

Proses Kreatif: Edison dan Bell dalam Revolusi Komunikasi (Andi Susilo) 
Meskipun Terman tidak pernah menyarankan bahwa task commitment sebaiknya menggantikan inteligensia didalam konsep kami dari bakat. Ia benar-benar menyatakan bahwa intelektualitas dan kecakapan jauh dari sempurna dikorelasikan.

\section{Kreativitas}

Ketika mendiskusikan tentang kreativitas, penting untuk mempertimbangkan masalah-masalah dimana ahli-ahli riset telah menemuinya didalam menetapkan hubungan antara tes kreativitas dan lebih banyak lagi substansi bakat. Sebuah topik utama yang dihadirkan oleh para peneliti yang berhubungan dengan apakah benar atau tidak pengujian terhadap berpikir divergen secara jelas mengukur kreativitas. Meskipun beberapa studi validasi telah melaporkan hubungan terbatas antara pengukuran berpikir divergen dan kriteria kemampuan kreatif (Dellas \& Gaier, 1970; Guilford, 1967; Shapiro, 1968; Torrance, 1969). Bukti riset untuk menafsirkan validitas hasil tes telah dibatasi. Sayangnya, beberapa jenis tes yang telah disatukan bertentangan dengan kriteria pada kehidupan nyata dari kemampuan kreatif. Bagaimanapun juga studi-studi longitudinal masa depan yang menggunakan secara relatif instrumen-instrumen baru dapat memperlihatkan bakat dengan menetapkan penafsiran validitas yang lebih tinggi, maka, meskipun berpikir divergen sungguh-sungguh sebuah karakteristik yang tinggi dari orang-orang kreatif, perhatian seharusnya dilakukan dalam penggunaan dan penafsiran hasil tes yang dirancang untuk mengukur kemampuan ini.

Beberapa ciri kreatif yang dijelaskan oleh Renzulli:

- Kelancaran, fleksibilitas, berpikir orisinal

- Terbuka terhadap pengalaman baru, bisa menerima sesuatu yang baru dan berbeda (bahkan tidak rasional) dalam berpikir, bertindak dan menghasilkan sesuatu untuk diri sendiri dan orang lain.

- Rasa ingin tahu, berani berspekulasi, senang petualangan, dan memiliki mental bermain; rela mengambil resiko dalam berpikir dan bertindak, bahkan melakukannya segera tanpa berpikir panjang.

- Peka terhadap detail, berani bertindak dan bereaksi terhadap rangsangan luar dari 
perasaan dan ide-ide.

\section{Tahap-tahap Proses Kreatif}

Pada dasarnya proses kreatif berlangsung sangat subyektif, misterius dan personal. Wallas mengemukakan bahwa proses kreatif melalui empat tahap, yaitu: persiapan, inkubasi, iluminasi dan verifikasi.

Tahap persiapan adalah ketika individu mengumpulkan informasi atau data untuk memecahkan suatu masalah. Mencoba memikirkan berbagai kemungkinan pemecahan terhadap masalah yang dihadapinya.

Tahap inkubasi, proses pemecahan masalah "dierami" dalam alam pra-sadar. Individu itu seolah-olah melupakannya. Tahap inkubasi ini dapat berlangsung lama bisa berhari-hari atau bahkan bertahun-tahun. Tetapi juga dapat berlangsung hanya beberapa jam atau menit, sampai timbul inspirasi atau gagasan memecahkan masalah.

Tahap Iluminasi yaitu suatu gagasan muncul untuk memecahkan masalah. Dan pada tahap terakhir yaitu verifikasi, gagasan yang muncul tersebut dievaluasi secara kreatif dan dihadapkan pada realitas.

Pengakuan orang-orang yang telah menunjukkan prestasi kreatif istimewa dalam lapangan ilmu alam dan seni mengungkapkan bahwa mereka mengalami keempat tahap proses kreatif tersebut. Sebelum melahirkan "Susunan Berkala Unsur-unsur Kimia", Dimitri Mendeleyev mengalami masa inkubasi yang cukup lama. Ahli matematika Perancis Henri Poncaire melahirkan "fungsi-fungsi Fuchsian" di dahului oleh masa inkubasi berhari-hari sampai akhirnya inspirasi datang secara mendadak ketika Poncaire sedang berekreasi. Sir Isaac Newton tokoh teori Fisika klasik berkebangsaan Inggris berpikir cukup lama yang membawanya kepada penemuan gaya gravitasi ketika kepalanya tertimpa buah apel. Komponis Austria berbakat W.A. Mozart menuliskan partitur-partitur musiknya begitu cepat terkadang ditulisnya di dalam suatu perjalanan, ia hanya tinggal menuliskan komposisi yang mengalir deras dari dalam benaknya setelah mengendap berhari-hari. Fyodor Dostoyevsky pengarang kelahiran Rusia menulis novel dan cerpennya berdasarkan pengalaman hidup yang keras bertahun-tahun dan mengalami

Proses Kreatif: Edison dan Bell dalam Revolusi Komunikasi (Andi Susilo) 
gangguan jiwa berat ketika hampir saja dijatuhi hukuman mati karena pembangkangan kepada pemerintah Rusia saat itu.

\section{Ciri-ciri kepribadian orang-orang kreatif}

Guilford mengemukakan bahwa dalam arti sempit kreativitas mengacu kepada kecakapan yang menjadi karakteristik orang-orang kreatif yaitu orisinalitas, fleksibilitas, kelancaran dan elaborasi. Kecakapan kreatif menentukan apakah individu dapat menampilkan perilaku kreatifnya sampai taraf tertentu. Ciri-ciri kreativitas dapat dibedakan kedalam ciri kognitif dan non kognitif. Ciri kognitif termasuk empat cara berpikir kreatif yang telah dikemukakan oleh Guilford diatas. Ciri-ciri non kognitif termasuk motivasi, sikap, dan kepribadian kreatif. Ciri-ciri non kognitif sama pentingnya dengan ciri-ciri kognitif karena tanpa ditunjang oleh kepribadian yang sesuai kemampuan kreatif seseorang tidak akan dapat berkembang.

Garwood (1964) melakukan studi terhadap para mahasiswa bidang sains. Mahasiswa yang tinggi kreativitasnya memiliki fleksibilitas kognitif yang tinggi, lebih dini tertarik pada sains, lebih dominan, pandai bergaul dan dapat menerima dirinya. Sedangkan Piers (1970) mengungkapkan bahwa orang-orang kreatif cenderung memiliki rasa ingin tahu yang besar, persisten, tidak puas dengan apa yang ada, percaya diri, otonom, bebas dalam pertimbangan, menerima diri, senang humor, intuitif dalam berpikir, tertarik kepada hal-hal yang kompleks, sensitif terhadap rangsangan dan toleran terhadap situasi yang tidak pasti.

Sri C. Utami Munandar (1977) mengemukakan tujuh ciri sikap kepercayaan dan nilai-nilai yang melekat pada orang-orang kreatif, yaitu: terbuka terhadap pengalaman baru dan luarbiasa, luwes dalam berpikir dan bertindak, bebas dalam mengekspresikan diri, dapat mengapresiasikan fantasi, berminat pada kegiatan-kegiatan kreatif, percaya pada gagasan sendiri dan mandiri.

Bagian berikut mengungkapkan manusia-manusia kreatif dalam perkembangan teknologi komunikasi. Inspirasi Edison dan Aplikasi Bell serta perbedaan proses kreatif ke arah penemuan diantara mereka berdua:

Majalah Ilmiah Informatika, Vol. 4, No. 10, Maret 2002

ISSN 1411-6413 1 


\section{Inspirasi}

Thomas Alva Edison yang tidak mampu menyelesaikan pendidikan formalnya, lahir pada tanggal 11 Pebruari 1847 di Milan, Ohio, Amerika Serikat. Guru sekolahnya melukiskan Ia sebagai anak yang tidak mengetahui apapun. Saat Edison berumur 12 tahun, ibunya mengeluarkannya dari sekolah dan mendidiknya di rumah.

Ia pertama kali mulai bekerja sebagai operator telegraph selama masa perang rakyat Amerika. Dari pekerjaan pertamanya ini ia bertemu dengan Samuel Morse, penemu kode Morse yang membuat telegraph menjadi sistem komunikasi jarak jauh pertama yang sukses.

Seniman, pemahat patung, desainer, pendiri dan presiden pertama Akademi Nasional Amerika dalam bidang perancangan, Morse yang memiliki berbagai bakat terkesan dengan Edison muda atas kemampuan dan kesuksesannya sebagai seorang promotor bisnis dan pengumpul dana. Ia membantu mengumpulkan 350.000 dollar dalam 2 minggu untuk menciptakan perusahaan Atlantic Telegraphic. Dan pada tahun 1958 meletakkan kabel Telegraph Atlantik pertama.

Pengalaman dan pelajaran yang didapatnya dari Morse itu merupakan kesempatan Edison untuk penemuan phonograph komersial pertama yang disebut "Triumph". Alat buatan Edison ini menggunakan sebuah silinder dibungkus kertas timah, diputar dengan tangan sementara sepucuk jarum mengikuti jalur yang ada pada silinder. Penyempurnaan segera dilakukan oleh beberapa orang, jalur pada silinder perekam dicetak hingga tinggi rendah jejak jarum pada jalur tadi bisa menimbulkan suara. Kelak Emil Berlinder mengembangkan suatu mesin yang disebut "Gramophone" mencetak jalur suara pada suatu piringan datar (piringan hitam) dengan gerakan kekiri dan kekanan. Sistem Berlinder ini yang selanjutnya diterima di seluruh dunia.

Pada umur 22 tahun, meskipun gagal dalam pendidikan, ia menemukan mesin Ticker Tape yaitu sebuah mesin untuk mencatat berita kawat yang dapat direkam, dijualnya seharga 40.000 dollar sebuah jumlah yang sangat besar waktu itu. Keberhasilannya ini telah menjadikannya seorang profesional mandiri. Satu dekade kemudian, penyempurnaannya terhadap pesawat telepon membawanya kepada kecukupan finansial. Ia segera pindah dari New York ke Newark, New Jersey dimana ia

Proses Kreatif: Edison dan Bell dalam Revolusi Komunikasi (Andi Susilo) 
mengelola laboratoriumnya sendiri di Menlo Park. Berdirinya Laboratorium ini dijadikan sebagai prototipe untuk laboratorium-laboratorium elektronik masa depan.

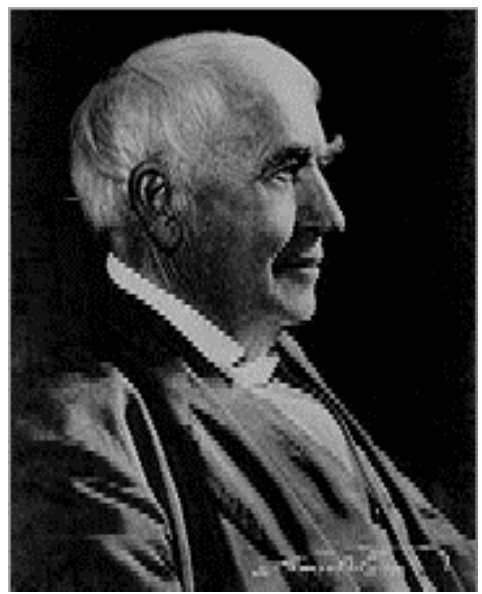

Edison memiliki sifat serendipitous, ia akan mengubah arah kerjanya ketika mendapatkan penemuan yang tidak terduga atau sebuah fenomena. Misalnya saat eksperimennya dengan lampu rumah, ia tidak tahu bagaimana mengoperasikan hukum Ohm. Ketika ditanyakan berapa jumlah percobaan yang membawanya kepada pengembangan sebuah tempat penyimpanan yang digerakkan baterai (storage battery), ia menegaskan hampir mendekati 50.000 percobaan, dari segi biaya penyimpan baterai Edison membutuhkan 3.000 dollar untuk pengembangan.

Edison mengatakan bahwa jenius adalah 1 persen inspirasi dan 99 persen kerja keras. Pandangan ini adalah sebuah deskripsi yang akurat dari metode-metode kerjanya. Sistemnya kembali menjadikan kenyataan ilmiah standar, dengan kata lain bukan riset biasa yang mengarahkan kepada riset terapan. Pendekatan ini sangat ditentang oleh salah satu pekerjanya seorang insinyur listrik muda yang cemerlang Nickoli Tesla, ia

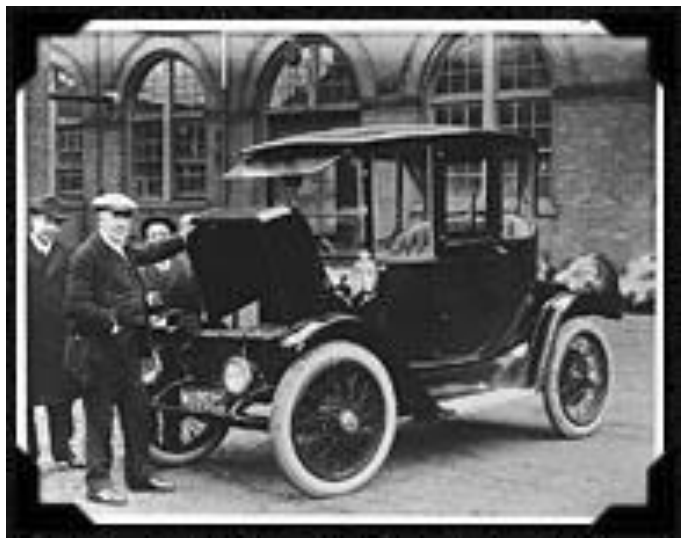
mengembangkan sistem pembangkit tenaga listrik dengan arus bolak-balik dimana Edison menggunakan sistem arus searah. Ia berpendapat bahwa Edison dapat menghemat waktu dan usaha dalam penerapan matematika. Sejumlah besar pemikiran dan pengorganisasiannya adalah berkat bantuannya.

Edison mencatatkan 1093 paten. Paten-paten ini mencakup penemuan dan penyempurnaan dari telegraph, gambar bergerak, baterai, gramophone, pembangkit daya dan telepon. Tidak kurang dari 389 paten yang berhubungan dengan penyempurnaan lampu pijar listrik dan pembangkit daya. 195 paten diperlukan sebelum ia menemukan gramophone atau Edison mengistilahkannya sebagai "phonograph" yang bekerja dengan 
memuaskan kemudian penyempurnaan-penyempurnaannya terhadap telepon membutuhkan lebih dari 34 paten. Ini berarti bahwa 618 patennya mendekati 58 persen dari total paten yang diambil dari penyempurnaan keempat alat tersebut. Hampir sepanjang hidupnya Edison mengalami pendengaran yang lemah, tetapi ia bisa mengatasi hambatan itu dengan kerja kerasnya yang mengagumkan.

Kesimpulan satu-satunya yang dapat digambarkan dari seluruh kehidupan Edison dalam bekerja, Edison memiliki kesulitan dalam mengembangkan ide-ide rancangannya.

\section{Aplikasi}

Alexander Graham Bell tidak memiliki kesulitan seperti yang dialami oleh Edison. Dilahirkan di Edinburg pada tanggal 3 Maret 1847, sebulan setelah Edison lahir. Bell berasal dari keluarga yang memiliki asosiasi studi speech (cara berpidato) dan elocution (cara menyampaikan pesan dengan ucapan). Ia belajar di Universitas College London sebelum beremigrasi ke Ontario, Kanada yang beriklim dingin dan kering di

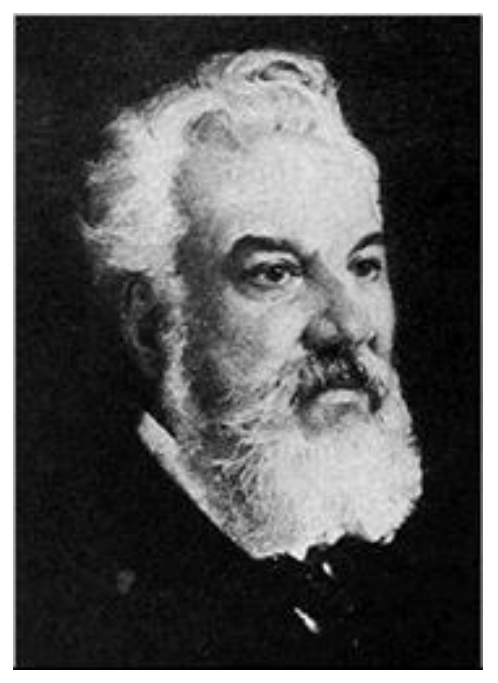
tahun 1870. Dalam waktu yang tidak terlalu lama, Ia menuju Amerika Serikat dan pada tahun 1872 mendirikan Boston School bagi penyandang cacat tuna rungu, dan melatih guru-guru untuk bidang itu.

Bell mengetahui bahwa gelombang suara dapat merenggangkan dan merapatkan udara yang dilewatinya. Ambisinya adalah untuk mengubah gelombang suara tersebut sehingga dapat dikonversikan ke dalam bentuk arus listrik fluktuasi untuk mengirim pesan melalui kabel ke lokasi tempat yang jauh dan selanjutnya dikonversikan lagi menjadi gelombang suara dimana manusia dapat mendengarnya. Ia melihat sebuah penerapan alat di dalam pekerjaannya sehari-hari dengan penyandang tuna rungu.

Usahanya dalam mengembangkan alat ini, Bell tidak menemukan bagian demi bagian, tetapi Ia menyatukan beberapa penemuan terpisah kedalam sebuah sistem kerja yang memberikan hasil menurut keinginannya. Penyatuan penemuan-penemuan terpisah tersebut berasal dari Hans Oersted untuk teori Electromagnetism, William Sturgeon untuk magnet listrik, Herman von Helmholtz untuk getaran suara (sound vibration), Proses Kreatif: Edison dan Bell dalam Revolusi Komunikasi (Andi Susilo) 
Michael Faraday untuk Induksi Elektromagnetik dan Frechman Leon Scott untuk Phonoautograph.

Pada tahun 1875 Bell mendemonstrasikan bagaimana ia berbeda dari Edison dalam pengembangan ide-ide, tidak dengan melibatkan sejumlah besar waktu dan uang. Ia meminta temannya di Massachusette Institute of Technology (MIT) untuk mengajarkannya teori-teori ketika Bell sedang memadukan peralatannya itu.

Telepon Bell pertama kali muncul di muka umum pada pameran 100 tahun kota Philadelphia tahun 1876. Bell mendapatkan paten bernomor 174.465. Paten teleponnya adalah yang pertama dari 18 paten atas namanya sendiri. Total keseluruhan patennya sebanyak 30 buah, 14 diantaranya atau hampir 47 persen berhubungan dengan telepon.

Motivasi Edison adalah 'Inspirasi Sepanjang Jalan'. Di dalam kasus Bell motivasi berasal dari sebuah kepatuhan kepada prinsip-prinsip dasar, mengaplikasikan dari apa-apa yang sudah diketahui atau ditemukan. Edison menghabiskan sejumlah besar waktu menyempurnakan yang sudah ada, yaitu penemuan-penemuan yang telah dibuatnya sendiri dan orang lain. Bell hampir tidak pernah membuat perbaikan-perbaikan dari yang sudah ada kecuali, tentu saja dari penemuan orisinilnya.

Meskipun menggunakan metode yang bertentangan dalam dekade antara tahun 1876 dan 1886, kedua orang ini telah menyempurnakan, membuat lebih ekonomis dan memungkinkan dilaksanakan pembuatannya di industri.

Tahun 1877 Edison menemukan Carbon Granule Microphone (Mikropon butir karbon), ini membuat penemuan Bell menjadi peralatan yang benar-benar praktis. Mikropon ini akan tetap menjadi pilihan yang disukai dari perusahaan-perusahaan pembuat telepon sampai tahun 1960-an. Sembilan tahun kemudian, Bell mendemonstrasikan kemampuan-kemampuan filtering terbatas kepada telepon dimana ia menyempurnakan phonograph Edison. Ia mengganti driver dengan Max disk dan menggunakan engraving needle dengan kecepatan terkontrol.

Meskipun mereka berbeda dalam pendekatan kepada suatu penemuan, kedua orang ini memberikan sebuah karakteristik yang lazim kepada ilmuwan dan ahli teknik. Mereka tidak memiliki gagasan yang murni tetapi hanya menyempurnakan peralatan yang sudah ada dan penemuan-penemuan mereka begitu besar pengaruhnya dalam 
kehidupan sehari-hari.

\section{Daftar Pustaka}

Alexander Graham Bell Scottish Inventor (1847-1922).

Alamat URL: http://www.lucidcafe.com/library/96mar/bell.html. 5 Januari 2002

Edison and an Electric Car 1913.

Alamat URL: http://americanhistory.si.edu/edison/ed_d_2.htm. 5 Januari 2002.

Editor Iwan Gayo, 1001 tokoh penemu paling berjasa bagi umat manusia, Penerbit Iwan Gayo Associates, cetakan ketiga 1987.

Grant, Greg, Bell and Edison Application vs inspiration A double $150^{\text {th }}$ anniversary, Majalah Elektor Electronics, Juli-Agustus 1997. Hal. 38-39.

Harris, Robert. Introduction to Creative Thinking (revisi 1 Juli 1998).

Alamat URL: www.virtualsalt.com/crebook1.htm. 1 September 2001.

Hart, Michael H., Seratus Tokoh yang paling berpengaruh dalam sejarah, Penerbit PT Dunia Pustaka Jaya, cetakan ke-11, 1989.

In Baum, S.M., Reis, S.M., \& Maxfield, L.R. (1998), The Three-Ring Conception of Giftedness by Joseph S. Renzulli, Ed. D.

Alamat URL: www.spuconn.edu/ nrcgt/sem/semart13.html. 31 Januari 2002

Supriadi, Dr. Dedi. Kreativitas, Kebudayaan \& Perkembangan Iptek. Penerbit CV. ALFABETA Bandung, 1994.

Thomas Edison American Inventor (revised: 28 Mei 2001).

Alamat URL : www.lucidcafe.com/library/96feb/edison.html. 5 Januari 2002.

Proses Kreatif: Edison dan Bell dalam Revolusi Komunikasi (Andi Susilo) 